\title{
Transdnestria, Abkhazia, Chechnya: Pros and Cons of the EU Intervention
}

Dmitry Polikanov *

As the EU's intervention and crisis management capabilities have been ripening and surviving their first tests in the Balkans or Congo, there is a growing interest in spreading this experience and introducing some "pilot projects" of intervention in other parts of the world. In this respect, the areas that attract most of the EU attention are situated in its near neighborhood. Stability in Moldova and in the South and the North Caucasus are especially important for the EU as it expands.

In methodological terms, there are considerable differences in the situations of these three areas. Firstly, there is a difference in the intensity of the conflict: it has nearly died down in Transdniestria, while in Abkhazia the confrontation is more intense, and in Chechnya the fighting is on-going.

Secondly, Russia's interest also varies. Moscow takes close to its heart the developments in Chechnya, and keeps its finger on the pulse in Abkhazia, but Moldova is hardly a top priority, even within the CIS policy of the Kremlin. The EU, on the contrary, is very much concerned about the Transdniestrian problem, and has a general interest in Abkhazia (as part of the South Caucasus). The European view on Chechnya has not substantially changed, even in light of the war on terror, although the statements on this issue have become milder. Nevertheless, Europe continues to exploit the Chechen issue as a lever to influence Russia's policy.

However, the methods of settlement of the various conflicts are similar, though the pace of conflict resolution differs. While Chechnya is already a part of the Russian Federation, and the task is to make it a 'normal' constituent member, Moldova is only moving toward a federal constitution, and Abkhazia is thus far unwilling to set up any federal structure with Georgia. Even the rhetoric of the parties is the same: Transdniestria is flooded with "criminal gangs" and "illicit arms dealers," Abkhazia is full of "terrorists" and "armed separatists mediating the drug trafficking," and Chechnya is the nest of "international terrorism" and "banditry." The slightest difference is that in Moldova and Georgia, despite official demonization of the enemy, there is some dialogue with the non-recognized entities, while Moscow does not want to conduct any negotiations with the Chechen rebels at the current stage, noting (fairly) that there is no unified command of warlords, and thus no representative to talk to.

Finally, the prospects for the intervention in the Moldovan case are more favorable, while Abkhazia is unlikely to fall under the patronage of a European or joint RussianEuropean force. As far as Chechnya is concerned, there is practically no chance that Moscow would allow any kind of international involvement in this region. There is seemingly a direct link between Russia's interest in an area and its openness to the pos-

* Dr. Dmitry Polikanov is Communication Advisor at the International Committee of the Red Cross, Moscow Delegation, Moscow, Russia. 
sibility of European intervention in that area. Unfortunately, in this formerly Soviet zone, Cold War stereotypes still prevail, and some disturbing wrestling goes on between Moscow, Brussels, and Washington. Therefore, the lower the level of Russia's interest, the better the future prospects of any interventionist operation.

The case of Transdniestria is a good example of such old-time rivalries, the futility of which is admitted by both parties. Both the EU and the United States have suddenly become very active in the area since the beginning of this year, when the conflicting parties succeeded in achieving some modest progress in resolving their eleven-year-old conflict. This cannot be explained only by the 'jealousy' of the EU and the U.S. towards Russian success, or by Moscow's attempts to play a key role in the reintegration of Moldova and, hence, in the future of Moldovan politics. Speaking in Cold War terms, it would be in the EU's interests to prevent the emergence of a Russian military outpost on its future eastern border. Besides, Moldova might be a good field on which to test the newly formed European forces and the entire CFSP, as well as the EU's potential cooperation with Russia in this sphere. This argument was already widely used in academic discussions in late 2001, when Transdniestria was named as the best opportunity to enhance interoperability and military cooperation in the course of joint Russia-NATO or Russia-EU action. Finally, the EU wants to maintain the pro-European orientation of Moldova and does not want to see the emergence of a 'black hole' with the concomitant challenges of illicit trafficking in arms, drugs, goods, and human beings on its border in 2007, when Romania may finalize its accession talks.

All these resulted in the levying of U.S.-EU sanctions against the Transdniestrian leadership, substantial political and financial pressure being placed on the Moldovan Government with a view to forcing a federative solution, and eventually in the idea of sending an EU-led and OSCE-mandated force to Transdniestria in order to guarantee the implementation of such a federation agreement. Nonetheless, the project has not yet succeeded - not only due to Russia's resentment, but also because of the lack of forces available to the European powers at the present time (Congo, Macedonia, Bosnia, Liberia, and Afghanistan have recently consumed too many troops and material resources).

The position of Moldova is also confusing. Chisinau is hesitating between Moscow (at least in part because it owes Russia $\$ 1$ billion in gas payments and because President Voronin's voters are mostly pro-Russian) and the EU (which grants financial assistance and promises various economic benefits). However unrealistic Moldova's aspirations about association membership by 2007 may be, the country is drifting more towards the direction of EU involvement. In September 2003, President Voronin even suggested changing the pentalateral format of negotiations and involving the EU as an official player. Bearing in mind that Moldova has to face presidential elections in a year or so, it is understandable that the issue of reintegration will be the most crucial question, and the party that helps to ensure the country's reintegration will become the number-one party in the future.

Russia's position is quite ambiguous in this respect. On the one hand, the Kremlin would be happy to get rid of the ammunition stored in Transdniestria, to curtail the 
peacekeeping mission (this is the general trend - the number of Russian peacekeeping forces is being reduced on an annual basis), and to comply with the Istanbul Summit decisions. This is why Russia agreed to forgive a $\$ 100$ million gas debt to Tiraspol, and additional high-level efforts were made to remove any obstacles to the withdrawal of the Russian armaments from the republic. On the other hand, it would not be pragmatic for Russia to lose the initiative now and to concede the role of the primary mediator, becoming just one of the parties to the post-conflict military guarantee operation. Moreover, even Russia's desire to keep some military presence by converting it into a base with full transparency and in accordance with the normal legal arrangements has some rationale behind it. The current policy vis-à-vis the CIS is to ensure Russia's regional leadership and stability in its neighborhood, partly through a limited military presence in certain key regions.

Since the project is now on standby and the Russian efforts to impede the EU-led intervention have succeeded, the Transdniestrian file will now concentrate on federation issues rather than military involvement. However, in general and in the long-term perspective, Moscow may probably agree to the OSCE-mandated mission or even a joint operation with the EU, unless it leads to a diminished role for Moscow, or 'Romanization' of Moldova (600,000 out of 4.2 million inhabitants have already accepted Romanian citizenship, in order to be able to penetrate the Schengen borders in the future).

Abkhazia seems to be the only problem in Russian-Georgian relations, being a source of all remaining quarrels between the parties. To a certain extent, Moscow faces a significant dilemma in case of Abkhazia. On the one hand, two-thirds of the population have taken Russian citizenship and can now apply to their Motherland for protection. Besides, there are some economic interests in retaining Abkhazia in the Russian orbit of influence - the Black Sea ports, which are valuable for commercial shipping and for stationing the Navy after its gradual withdrawal from NATO-listing Ukraine; the coast's popularity as a cheap tourist destination; its utility as a transit route. On the one hand, Russia has to keep in mind Georgia's territorial integrity, and has no desire to admit Abkhazia into the Russian Federation (Moscow has persistently rejected any initiatives of this kind set forth by Sukhumi). Meanwhile, it is clear that in such a situation Russia will never establish a full blockade of Abkhazia. But without such a blockade, Georgia will hardly ever be able to restore its sovereignty, to ensure the return of the IDPs, etc. A military solution is equally unworkable, and Tbilisi realizes this well, despite its belligerent rhetoric.

Russia's interest in Georgia is not high nowadays, and Russian policy on this issue is driven mostly by inertia. As for the real decision-makers, such as the Georgian presidential administration, they do not really focus on relations with Russia and pursue a wait-and-see policy. Some hardliners in Russian military circles do not go beyond the exchange of noisy statements with the Georgian anti-Russian radicals. In fact, after failing to normalize relations with Russia in the early 1990s (the Yeltsin regime missed the chance of integrating Georgia, which was seeking Russia's patronage), Tbilisi has chosen pro-European and anti-Russian sentiments as a basis for the consolida- 
tion of Georgian society. Afterwards, this caused a reaction of delayed irritation on the part of the Kremlin, and even economic relations became highly politicized. There are a (very) few pragmatic reasons for Russia to develop ties with Georgia, e.g. the Gazprom and RAO EES (Russian energy monopoly) attempts to conquer the Georgian market and to use it as a transit route to Turkey; or the efforts to restore the railroad connection with Armenia via Georgia; or the regional initiative of North Ossetia seeking access to the Black Sea ports. Meanwhile, for political reasons Georgia is not particularly interested in Russian investments, and has implemented a number of projects that may hurt Russian economic interests (TRASECO, for example, which is much more viable than the Baku-Ceyhan pipeline project). Therefore, the lack of an economic basis to the relationship impedes progress in other spheres.

The Sochi agreements reached by the Russian and Georgian presidents in early 2003 seemed to represent a breakthrough. Both parties tried to come to a consensus on small topics without straying into heated political debate, and then hoped to move from the policy of small steps toward mutual understanding and potential compromises in other spheres. The restoration of the Inguri hydropower plant or the railroad via Georgia to Armenia would be in the interests of both parties, even if their implementation becomes tied to the return of Georgian IDPs to Abkhazia. However, even a strategy of such modest but joint successes failed, and fell victim to pre-electoral politicizing.

Under these circumstances, Moscow's policy is mostly to wait for the results of the parliamentary elections in Georgia and carry out inert dialogue until the end of the Shevardnadze era, so that the Kremlin may resume substantive talks with the successor of the current regime without mutual accusations. Another idea would be to 'lock' all parts of Georgia (Abkhazia, Adjaria, South Ossetia, etc.) in internal debate on the reorganization into the federation, with minimal Russian involvement in this process. In this case, the EU intervention (jointly with Russia, of course) might be acceptable to guarantee the implementation of such a federation agreement, as in Moldova. Nonetheless, in the near future one can hardly expect any mission of this kind, due to the lack of preconditions for its existence and the opposition of the Abkhazian side to any foreign military presence, however benign.

Finally, as far as Chechnya is concerned, the prospects for any form of external intervention are even gloomier. On the Russian side, any interference of this kind would immediately be treated as a hidden attempt to support the separatist elements in the break-away republic, since any separation of the warring parties (if it may technically happen, bearing in mind the complexity in the field and the disposition of the Chechen militants in small cell-type detachments in the mountainous regions or in maquis-resistance style in the cities and district centers of Chechnya) will mean a de facto recognition of the Chechen rebels. Theoretically, taking the position of the devil's advocate, it would be good to have Europeans involved, in order to make them understand the situation in the field better and to force them to share responsibility for any future disorder à la 1996-99, or in the vein of post-war Iraq. But this will never happen, and it is not even in the interests of the Europeans themselves. 
The general situation in Chechnya has been affected by the intensification of attacks, which occurs simultaneously with the appearance of new Russian mantras of "normalization." Sociological polls indicate, however, that the number of real separatists does not exceed 18-20 percent of the populace, while the rest of the population, for different reasons (fear of economic incapacity, Russian military might, sincere desire not to break away from Russia, etc.), supports the idea of staying within the Russian Federation. The popularity rating of Aslan Maskhadov, the alleged leader of the resistance, is extremely low, and is comparable to the rating of Akhmad Kadyrov, the current head of the administration in Chechnya and potential president of the republic. There is little ideological basis for many of the attacks conducted by the rebels-some of them are of a purely criminal character, while others are perceived as acts of revenge against the federal troops for lost relatives or human rights abuses. But this has nothing to do with Islam (such an ideological justification for the conflict is more typical of the Arab mercenaries fighting in Chechnya) or a widely shared desire for a war for independence on the part of the people, whose interests the rebels claim to defend.

Another feature is the persistence of Moscow in imposing "normalization" via "Chechenization." Nowadays, people fear and hate Akhmad Kadyrov and his guards more than they fear and hate the federal troops or the rebels. And the situation has been moving slowly to the verge of civil war due to various economic interests of the clans in Chechnya, while Russia is instrumentalized and, hence, becomes the victim of internal struggle rather than facing a real separatist challenge. The obvious disadvantage of such a policy is the ongoing blackmailing on the part of Kadyrov-in order to prevent new bloodshed on the eve of the spring 2004 presidential elections in Russia, and to avoid Kadyrov's transformation into a rebel leader (with his well-armed guard of several thousand people, many of whom are pardoned ex-militants), Moscow had to wager all its stakes on Kadyrov's victory at the 2003 October elections and help him to get rid of other strong pro-Moscow candidates who might have made a good alternative (e.g., Aslanbek Aslakhanov or Malik Saidullaev, who are much more popular with the Chechen people).

The flaw of such an approach is the serious blow it strikes at the hopes of Chechen society. Any sincere desire to change Chechnya's fate that emerged from the March 2003 constitutional referendum, and the illusion of the freedom of choice given at the October elections, will be ruined by such clumsy actions of the Kremlin. Moreover, Moscow may suffer in the short term if Kadyrov succeeds in imposing his version of the treaty on the division of powers between the federal center and Chechnya (which should be signed in December 2003). Kadyrov may easily outmaneuver Moscow, gaining extremely extensive autonomy, and Russia will eventually return at best to the situation of 1996-99, when Chechnya was the black hole on the Russian map swallowing federal money and being totally out of the control of the central government. In the long run, the only way out for the Kremlin will be to build at least a proto-civil society in Chechnya, in order to raise new politicians who will be young, not 'allergic' to Russia, not prone to Islamic fundamentalism, and capable of consolidating Chechen society (by overcoming the clan divisions as well, if possible). In this respect, Kadyrov 
may be regarded as some kind of interim figure and a bugaboo to the Chechens (i.e., something like "while the Russians were in charge, there was some sort of order; pensions and salaries were paid, roads and schools were rebuilt, housing was gradually provided, etc. and now the money is stolen, reconstruction is fictitious, people are taken away by the Kadyrov guards and the Chechen police is too weak to control the situation.")

Under these circumstances, one can hardly expect any intervention on the part of the EU save for its declarations on human rights abuses, which are targeted against Moscow. Any plans of establishing a UN-administered or any other protectorate, such as Kosovo or East Timor, are doomed to failure in the foreseeable future. At the same time, as relations with the West improve, Russia may consider in the middle term some sort of joint operation against the rebels, who are supposed to be connected with international criminal and terrorist networks. Moreover, as the process of 'normalization' proceeds, there will be even less desire on Russia's part to have any interference and special treatment being given to Chechnya, in contrast to other Russian regions. This also includes the sphere of international humanitarian assistance, which Moscow may wish to put under its own control and to tighten its grip on the distribution and management of humanitarian operations.

Thus, the applicability of the newly-born EU force may be quite low on the postSoviet stage in the immediate future, but its intervention at later stages, when political conditions are ripe, in cases such as Transdniestria and Abkhazia cannot be totally ruled out in the medium-term and long-term perspective. Much will depend, in this respect, on Russia's willingness to collaborate and on the ability of the parties to overcome their Cold War rivalries and the setbacks in their mentality that these produce. 